\title{
Editorial \\ Organic Fertilization in Maize Cropping Systems: Measures to Reduce N Losses
}

\author{
Hans-Werner Olfs (D)
}

check for updates

Citation: Olfs, H.-W. Organic Fertilization in Maize Cropping Systems: Measures to Reduce N Losses. Agronomy 2021, 11, 793. https://doi.org/10.3390/ agronomy11040793

Received: 26 March 2021

Accepted: 13 April 2021

Published: 17 April 2021

Publisher's Note: MDPI stays neutral with regard to jurisdictional claims in published maps and institutional affiliations.

Copyright: (C) 2021 by the author. Licensee MDPI, Basel, Switzerland. This article is an open access article distributed under the terms and conditions of the Creative Commons Attribution (CC BY) license (https:// creativecommons.org/licenses/by/ $4.0 /)$.
Plant Nutrition and Crop Production, Faculty of Agricultural Science and Landscape Architecture, University of Applied Sciences Osnabrück, Am Krümpel 31, D-49090 Osnabrück, Germany; h-w.olfs@hs-osnabrueck.de; Tel.: +49-541-969-5135

Maize is one of the most important crops around the world. It is used as staple food for humans as well as a major source of both grain feed and silage fodder for livestock, as feedstock for the production of ethanol fuel, and for methane production in biogas plants. Starch from maize can also be made into plastics and many other chemical products.

In many regions, organic fertilizers (e.g., products derived from human and animal excreta, composted materials, and crop residues) are a significant nutrient source in maize production. However, maize is a crop with a rather low growth rate during the early seedling stage after germination, and substantial nitrogen losses from applied organic fertilizers might occur during this period. In many field situations, ammonia emissions to the atmosphere shortly after the application of organic fertilizers in the field and nitrate leaching after microbial mineralization/nitrification are obviously the most predominant processes contributing to $\mathrm{N}$ losses from maize-based cropping systems. In recent years, different approaches have been developed to minimize these losses and have been introduced into contemporary farming practice. This Special Issue intends to give a broad overview focusing on experiments with maize from pot to field scales.

Based on a meta-analysis using 133 maize studies conducted worldwide, Wei et al. [1] concluded that a partial substitution of mineral fertilizer by organic fertilizer in maize cropping systems led to higher yields, reduced $\mathrm{N}$ losses, and also to carbon sequestration into the organic soil C pool. Overall a substitution rate of $40-60 \%$ mineral $\mathrm{N}$ with organic $\mathrm{N}$ resulted in optimal maize yields. This was confirmed by data from long-term field studies in China [2,3], Austria [4] and Canada [5]. An 11-year field experiment conducted by Wang et al. in northeast China with a monoculture maize cropping system revealed that combined mineral and organic fertilizers in a so-called "integrated soil-crop system management" approach achieved equal yields with a high-yielding strategy, while farmers' practice was less well-performing [2]. In such an integrated approach, not only are aspects of fertilizer application rates and timing relevant, but soil tillage intensity and seeding density should also be adapted to soil and weather conditions. Based on data from a 10-year maize trial in the North China Plain comparing four different rates of $\mathrm{N}$ fertilizer and cattle manure, Fan et al. showed that lower yields in the organic treatments in the first year disappeared as time progressed [3]. A strong increase in soil nitrate concentration after harvest, which is a good predictor for $\mathrm{N}$ leaching losses into the groundwater, was found at the highest fertilizer level for mineral as well as for organic treatments. Interestingly, at low application rates, the partial factor productivity as well as the agronomic efficiency for nitrogen, phosphorous and potassium were higher for mineral compared to organic treatments, and overall a significantly higher $\mathrm{N}$ recovery efficiency was found for plots with mineral $\mathrm{N}$ application [3]. Soil samples taken at the end of the maize growing season after 27 years of compost application (with and without extra mineral $\mathrm{N}$ ) revealed that physicochemical soil properties were influenced (e.g., higher soil organic C and total $\mathrm{N}$ contents, higher $\mathrm{pH}$ values) [4]. Kurzemann et al. concluded that composts are a valuable nutrient source for plants [4]. Furthermore, long-term compost application increased soil 
microbial biomass and microbial activity. Interestingly, the composition of the bacterial community showed significant differences due to the compost treatments; both richness and diversity of the fungal community was rather unaffected [4].

In several regions (e.g., North America, West Europe) maize is grown as fodder crop, and farmers have often used too much of the farm-based organic fertilizers (i.e., slurry, manure) on their land, leading to severe problems in non-agricultural ecosystems. In the European Union, a set of new legislation was introduced to reduce nitrate concentrations in groundwater aquifers and surface waters as well as high ammonia losses into the atmosphere. To evaluate the impact of these legislative measures, Velthof et al. reviewed the situation in the Netherlands since the 1980s based on a literature review and a time series of nitrogen and phosphorus uses, yields, surpluses, and losses for silage maize cropping systems [6]. Interestingly, the clear reduction in $\mathrm{N}$ input via organic fertilizers in the Netherlands was mainly due to the implementation of regulations focusing on maximum permissible $\mathrm{P}$ application rates. As expected, this reduced $\mathrm{N}$ input to silage maize in the 1995-2018 period resulted in a considerable decrease in nitrate leaching. Furthermore, new application techniques for liquid manures (e.g., trailing hose/shoe, slot injection) have been implemented, leading to drastically reduced ammonia emissions after the field application of these farm-based fertilizers. However, Velthof et al. [6] conclude that although the implementation of the stricter environmental regulations since the mid-1980s has resulted in lower $\mathrm{N}$ and $\mathrm{P}$ losses from silage maize cultivation in the Netherlands, the EU and national water quality standards have still not been met, and new challenges related to the use of organic fertilizers (e.g., greenhouse gas emissions) are appearing.

Since the early 1980s, nitrate leaching losses from crop production systems has been the core focus of many research groups worldwide (e.g., [7-9]). Many field experiments have been conducted to measure ammonia emissions from applied organic fertilizers (e.g., [9]). Additionally, slurry acidification has been proposed as a very efficient way to reduce ammonia emissions under field conditions. Fangueiro et al. [10] critically reviewed studies that have been performed to understand the effects of slurry acidification and concluded that acidification enhances the fertilizer value of slurry. In a pot trial with maize, Regueiro et al. [11] were able to show that reduced $\mathrm{pH}$ in the slurry after acidification also increased the water-extractable phosphorous fraction of the tested organic fertilizer products and subsequent $\mathrm{P}$ uptake by the maize plants compared to the untreated products.

As alternative approaches to decreased ammonia emissions after the application of liquid organic fertilizer, surface banding with a trailing hose or the incorporation of slurry into the upper soil horizon (trailing shoe or slot injection) are well established techniques. Slurry injection has also been tested in pot experiments [11] and in many field trials (e.g., [12-14]) as a substitute for band-applied mineral NP (so-called "starter") fertilizer in the last years. In a five-year field study in British Columbia (Canada), Hunt and Bittman studied the effects of sludge (i.e., the thick fraction of separated dairy slurry) injection on maize growth and nutrient uptake compared to mineral fertilizer application at several NP levels [5]. With the injected sludge, sufficient nitrogen and phosphorous were provided for the early vegetation period as well as for the full season growth, leading to equivalent yields at final harvest. Based on the data presented by Hunt and Bittman [5] and other studies $[12,14,15]$, it can be concluded that injecting liquid organic manures is an adequate way to replace mineral fertilizer, which finally enables farmers to lower the P surpluses at farm level.

However, there are also some disadvantages related to slurry injection. Based on results from several field studies, it can be concluded that the injection of slurry often leads to increased $\mathrm{N}_{2} \mathrm{O}$ emissions (e.g., [16]), while no consistent effects of slurry surface application have been reported. Wei et al. [1] concluded from their meta-analysis based on 133 studies with maize that no effect of organic compared to mineral fertilizer use on $\mathrm{N}_{2} \mathrm{O}$ emissions were found. On the other hand, Liu et al. found lower $\mathrm{N}_{2} \mathrm{O}$ losses for organic treatments in a long-term field experiment comparing mineral $\mathrm{N}$ treatments with combined mineral fertilizer/manure treatments in a maize-wheat rotation pattern in the 
North China Plain [17]. One option to lower $\mathrm{N}_{2} \mathrm{O}$ emissions when slurry is injected as a starter fertilizer for maize is the addition of nitrification inhibitors (NI) into the slurry. In field trials with different NI products located in Germany, Herr et al. could demonstrate that NI application reduced the annual $\mathrm{N}_{2} \mathrm{O}$ emission between $27 \%$ and $62 \%$ compared to the injection treatment without NI [18]. Obviously, the effects of different slurry application techniques as well as additives (NI, acid) on nitrogen use efficiency and $\mathrm{N}$ losses depend on the specific field situation (defined as the interaction of soil and weather conditions). An alternative application method using fertigation techniques (drip irrigation and pivot) is proposed by Guido et al. [19]. In a two-year field test at two different sites in northern Italy, they could show that both irrigation systems were suitable for fertigation, but it was essential that the digestate was adequately filtrated. If the whole process is properly managed, filtered slurry can be applied during the growing season of maize covering the $\mathrm{N}$ demand of the crop.

Funding: This research received no external funding.

Acknowledgments: I thank all the authors for submitting their manuscripts to this Special Issue and for the open-minded and thorough consideration of comments provided by the excellent reviewers and the editor. Thanks also to the Agronomy editorial staff for the professional support during all steps of the process that finally made this Special Issue possible.

Conflicts of Interest: The author declares no conflict of interest.

\section{References}

1. Wei, Z.; Ying, H.; Guo, X.; Zhuang, M.; Cui, Z.; Zhang, F. Substitution of Mineral Fertilizer with Organic Fertilizer in Maize Systems: A Meta-Analysis of Reduced Nitrogen and Carbon Emissions. Agronomy 2020, 10, 1149. [CrossRef]

2. Wang, Y.; Cao, Y.; Feng, G.; Li, X.; Zhu, L.; Liu, S.; Coulter, J.A.; Gao, Q. Integrated Soil-Crop System Management with Organic Fertilizer Achieves Sustainable High Maize Yield and Nitrogen Use Efficiency in Northeast China Based on an 11-Year Field Study. Agronomy 2020, 10, 1078. [CrossRef]

3. Fan, F.; Zhang, H.; Alandia, G.; Luo, L.; Cui, Z.; Niu, X.; Liu, R.; Zhang, X.; Zhang, Y.; Zhang, F. Long-Term Effect of Manure and Mineral Fertilizer Application Rate on Maize Yield and Accumulated Nutrients Use Efficiencies in North China Plain. Agronomy 2020, 10, 1329. [CrossRef]

4. Kurzemann, F.R.; Plieger, U.; Probst, M.; Spiegel, H.; Sandén, T.; Ros, M.; Insam, H. Long-Term Fertilization Affects Soil Microbiota, Improves Yield and Benefits Soil. Agronomy 2020, 10, 1664. [CrossRef]

5. Hunt, D.; Bittman, S. Precision Injection of Dairy Sludge on Crop Yield and N and P Uptake in Juvenile and Mature No-Till Silage Corn. Agronomy 2021, 11, 370. [CrossRef]

6. Velthof, G.; Van Schooten, H.; Van Dijk, W. Optimization of the Nutrient Management of Silage Maize Cropping Systems in The Netherlands: A Review. Agronomy 2020, 10, 1861. [CrossRef]

7. Di, H.J.; Cameron, K.C. Nitrate leaching in temperate agroecosystems: Sources, factors and mitigating strategies. Nutr. Cycl. Agroecosyst. 2002, 64, 237-256. [CrossRef]

8. Schröder, J.J.; De Visser, W.; Assinck, F.B.T.; Velthof, G.L. Effects of short-term nitrogen supply from livestock manures and cover crops on silage maize production and nitrate leaching. Soil Use Manag. 2013, 29, 151-160. [CrossRef]

9. Powell, J.M.; Jokela, W.E.; Misselbrook, T.H. Dairy Slurry Application Method Impacts Ammonia Emission and Nitrate Leaching in No-Till Corn Silage. J. Environ. Qual. 2011, 40, 383-392. [CrossRef] [PubMed]

10. Fangueiro, D.; Hjorth, M.; Gioelli, F. Acidification of animal slurry-a review. J. Environ. Manag. 2015, 149, 46-56. [CrossRef] [PubMed]

11. Regueiro, I.; Siebert, P.; Liu, J.; Müller-Stöver, D.; Jensen, L.S. Acidified Animal Manure Products Combined with a Nitrification Inhibitor Can Serve as a Starter Fertilizer for Maize. Agronomy 2020, 10, 1941. [CrossRef]

12. Schröder, J.J.; Ten Holte, L.; Brouwer, G. Response of silage maize to placement of cattle slurry. NJAS Wagening. J. Life Sci. 1997, 45, 249-261. [CrossRef]

13. Federolf, C.-P.; Westerschulte, M.; Olfs, H.-W.; Broll, G.; Trautz, D. Enhanced nutrient use efficiencies from liquid manure by positioned injection in maize cropping in northwest Germany. Eur. J. Agron. 2016, 75, 130-138. [CrossRef]

14. Pedersen, I.F.; Rubæk, G.H.; Nyord, T.; Sørensen, P. Row-injected Cattle Slurry can Replace Mineral P Starter Fertiliser and Reduce P Surpluses without Compromising Final Yields of Silage Maize. Eur. J. Agron. 2020, 116, 126057. [CrossRef]

15. Westerschulte, M.; Federolf, C.-P.; Trautz, D.; Broll, G.; Olfs, H.-W. Slurry injection with nitrification inhibitor in maize: Plant phosphorus, zinc, and manganese status. J. Plant Nutr. 2018, 41, 1381-1396. [CrossRef]

16. Herr, C.; Mannheim, T.; Müller, T.; Ruser, R. Effect of cattle slurry application techniques on $\mathrm{N}_{2} \mathrm{O}$ and $\mathrm{NH}_{3}$ emissions from a loamy soil. J. Plant Nutr. Soil Sci. 2019, 182, 964-979. [CrossRef] 
17. Liu, D.; Sun, H.; Liao, X.; Luo, J.; Lindsey, S.; Yuan, J.; He, T.; Zaman, M.; Ding, W. $\mathrm{N}_{2} \mathrm{O}$ and NO Emissions as Affected by the Continuous Combined Application of Organic and Mineral N Fertilizer to a Soil on the North China Plain. Agronomy 2020, 10, 1965. [CrossRef]

18. Herr, C.; Mannheim, T.; Müller, T.; Ruser, R. Effect of Nitrification Inhibitors on $\mathrm{N}_{2} \mathrm{O}$ Emissions after Cattle Slurry Application. Agronomy 2020, 10, 1174. [CrossRef]

19. Guido, V.; Finzi, A.; Ferrari, O.; Riva, E.; Quílez, D.; Herrero, E.; Provolo, G. Fertigation of Maize with Digestate Using Drip Irrigation and Pivot Systems. Agronomy 2020, 10, 1453. [CrossRef] 